\title{
A Stratified Approach for Cushing's Syndrome Diagnosis
}

\author{
Mervin Chavez ${ }^{1}$, Joselyn Rojas ${ }^{1,2}$, Miguel Aguirre ${ }^{1}$, Marjorie Villalobos ${ }^{1}$, Juan Salazar ${ }^{1}$, Luis Bello ${ }^{1}$, Roberto \\ Añez ${ }^{1}$, Luis Olivar ${ }^{1}$, María Calvo ${ }^{1}$, Yaneth Herazo-Beltrán ${ }^{3}$, Maricarmen Chacín González ${ }^{3}$, \\ Jhoalmis Sierra-Castrillo ${ }^{4}$ \& Valmore Bermúdez-Pirela ${ }^{1,3}$ \\ ${ }^{1}$ Endocrine and Metabolic Diseases Research Center, "Dr. Félix Gómez," School of Medicine. University of Zulia, \\ Maracaibo 4004, Venezuela \\ ${ }^{2}$ Pulmonary and Critical Care Medicine Department, Brigham and Women's Hospital, Harvard Medical School, \\ Boston, MA, USA \\ ${ }^{3}$ Universidad Simón Bolívar, Facultad de Ciencias de la Salud, Barranquilla, Colombia \\ ${ }^{4}$ Universidad de Santander (UDES), Programa de Bacteriología y Laboratorio Clínico, Cúcuta, Colombia \\ Correspondence: Valmore Bermúdez-Pirela, MD, MgS, MPH, PhD. Universidad Simón Bolívar, Facultad de \\ Ciencias de la Salud, Barranquilla, Colombia. E-mail: v.bermudez@unisimonbolivar.edu.co
}

Received: May 2, 2019 Accepted: July 3 18, 2019 Online Published: August 15, 2019

doi:10.5539/gjhs.v11n10p55 URL: https://doi.org/10.5539/gjhs.v11n10p55

\begin{abstract}
Cushing's syndrome is an endocrine disorder broadly renowned as a diagnostic challenge. From the initial clinical presentation up to the identification of the underlying etiology, it is necessary to adhere to a logical and stratified plan of action, directed to the correlation of signs and symptoms to the physiopathology of the syndrome, in order to accurately establish a diagnosis and adequate treatment. From stages as early as the patient's first clinical evaluation, the physician should be specially attentive of a constellation of clinical signs which strongly suggest the diagnosis of Cushing's syndrome, such as the presence of a "moon face", a "buffalo hump", cutaneous atrophy, proximal muscle weakness and purplish cutaneous striae, among others. Based off these findings, laboratory analyses are necessary for the detection of hypercortisolism. According to these results, and if physiologic causes are ruled out, pathologic hypercortisolism is confirmed. Lastly, a complex array of diagnostic tests must be navigated to identify the primary origin of the disorder. Thus, the diagnosis of Cushing's syndrome requires a logically structured algorithm of action, constructed off its pathophysiologic implications, in order to optimize time, resources and the interdisciplinary workgroup required for its consecution, and offer patients the possibility of a better quality of life. It is also important to highlight the need for a stratified approach in patients with metabolic disturbance given that medical professionals may simply treat the patient for obesity not recognizing the presence of the complicating condition Cushing's syndrome.
\end{abstract}

Keywords: Cushing's syndrome, Cushing's disease, cortisol, central obesity, ACTH

\section{Introduction}

Cushing's syndrome (CS) is an aggregation of signs and symptoms resultant from prolonged exposition to inappropriately elevated levels of serum glucocorticoids (Pivonello, De Matino, De Leo, Lombardi, \& Colao, 2008). Although the most frequent cause is the exogenous administration of pharmacologic preparations of these hormones, the endogenous aetiology of CS is often undervalued (Makras, Toloumis, Papadogias, Kaltsas, \& Besser, 2006). Currently, the incidence of CS is estimated at $2-5$ cases per million inhabitants per year, and it is $3-$ 8 times more frequent in women than in men (Karmath \& Babatunde, 2008). The age of diagnosis varies depending on the underlying aetiology, while Cushing's Disease (CD) prevails fundamentally in women aged 2545 years, ectopic Adrenocorticotropic hormone (ACTH) secretion syndromes dominate the demography beyond 50 years of age.

On the other hand, ACTH-Independent varieties of CS significantly rise in incidence starting at 40 years of age. Among children, $50 \%$ of cases of CS are due to adrenal carcinoma, followed in incidence by CD. Cases of CS during pregnancy are exceptional and are often ACTH-Independent presentations, particularly in the form of adrenal adenoma (Lahera-Vargas \& da Costa, 2009).

Nevertheless, these figures are presumed to be much higher at the expense of a significant number of CS 
presentations with few clinical manifestations, which are usually ignored or managed as other unique pathologies, particularly Type 2 Diabetes Mellitus (T2DM) (Murakami et al., 2010) or polycystic ovary syndrome (Fegan et al., 2007). Furthermore, subclinical cases of CS, characterised by the incidental discovery of adrenal masses in the absence of clinically suggestive findings, often remain undiagnosed and contribute to the inexactitude of the previously cited prevalence estimations (Terzolo, Pia, \& Reimondo, 2012).

Moreover, the diagnostic management of CS represents a challenge for clinicians, not only due to the ubiquity of its clinical manifestations but also because of the complex decision-making required regarding the ample catalogue of tests which may be performed. Clinical expressions of CS include elements that are common reasons for consultation of other pathologies, such as hirsutism and menstrual disruptions in women (Master-Hunter \& Heiman, 2006), neuropsychiatric symptoms of the affective spectrum (Belmaker \& Agam, 2008), and especially weight gain (Baid et al., 2009). Likewise, cardiovascular risk factors such as obesity, dyslipidemia, arterial hypertension, dysglycemia and insulin resistance may also be part of CS and heighten the risk of aggregate morbidities through its association with prothrombotic and proinflammatory states (Arnaldi, Mancini, Polenta, \& Boscaro, 2004). Indeed, cardiovascular disease represents the first cause of mortality in patients with CS, followed by poorly-controlled diabetes mellitus and complicated opportunistic infections (Clayton, Raskauskiene, Reulen, \& Jones, 2011); risk for these comorbidities is especially alarming in patients with CS since they display a doubled risk of all-cause mortality (Clayton, 2010).

In effect, CS predisposes to the development of several pathologies that represent a heavy burden on worldwide public health systems (Abegunde \& Anderson, 2006), particularly cardiovascular disease, which is considered an international epidemic (Vartiainen, 2008) and represents the first cause of morbidity and mortality not only globally (World Health Organization [WHO], 2010) but also in Latin America (Ministerio del Poder Popular para la Salud de Venezuela [MPPS], 2009). Thus, the establishment of a diagnostic protocol for this syndrome becomes a valuable tool for health professionals, as it directs to the accurate detection of all cases, optimising time and resources, and contributing to the opportune rehabilitation of affected patients.

\section{General Aspects}

The first clinical description of what it is known nowadays as CS was published by neurosurgeon Harvey Cushing in 1913, titled "The pituitary body and its disorders" (Cushing, 1913), where he proposes adrenal hyperfunction caused by a basophilic hypophyseal tumour to be the pathophysiological basis of this clinical picture, based on observations made in humans and dogs. Afterwards in 1932, Bishop and Close first denominate the previously described clinical impression as "Cushing's Syndrome" after its original reporter (Bishop \& Close, 1932). Finally, in 1944, Fuller Albright identifies adrenal hyperfunction as the component common to all presentations of CS and redefines the aggregate presence of basophilic hypophyseal tumours as "Cushing's Disease" (Albright, 1944).

In CS, overactivity of the Hypothalamus-Hypophysis-Adrenal axis (HHAA) is the mainstay pathophysiologic feature. In the hypothalamus, this axis is represented by the parvocellular population of the paraventricular nucleus, which secretes Corticotropin-releasing Hormone (CRH) in response to "stressor" stimuli, particularly extreme temperatures, hypoglycemia (Denver, 2009) and psychogenic distress (Aron, 2005). Proinflammatory cytokines such as IL-1, IL-2, IL-6, TNF and IFN- $\gamma$ also favour the secretion of CRH (Slominski, Wortsman, Luger, Paus, \& Solomon, 2000). This hormone, a polypeptide of 41 amino acids, stimulates the secretion of corticotropin or Adrenocorticotropic (ACTH) in corticotropic cells of the adenohypophysis (Denver, 2009).

ACTH, a 39-amino acids polypeptide, is a proteolytic product of its proteic precursor, pro- opiomelanocortin (POMC) (Beuschlein \& Hammer, 2002). A diversity of proteolytic patterns for POMC gives way to a plurality of products, including various melanocyte-stimulating hormone, lipotropins and endorphins; some of which participate in the development of CS (Oliver, Davis, \& White, 2003). ACTH induces corticosteroid synthesis, mainly cortisol, in the adrenal cortex, particularly in the fascicular zone (Nishimoto et al., 2010). In turn, cortisol completes the functional structure of the HHAA through negative feedback, by inhibiting the secretion of CRH and ACTH in the hypothalamus and adenohypophysis, respectively (Faghih, Savla, Dahleh, \& Brown, 2011). This key element allows the system to maintain hormonal serum concentrations under strict control. However, hyperfunction at any of these points leads to abnormally elevated glucocorticoid levels, which is the pathophysiologic principle of CS.

This description is a simplistic view of the phenomena implied in CS. Nonetheless, the discovery of an abundance of distinct potential etiologies leading to CS has expanded Albright's initial classification into the current pathophysiologic categorisation, where the participation of ACTH is the pivotal discriminating criterion (Table 1) (Boscaro \& Arnaldi, 2009). Most cases of CS represent ACTH-Dependent profiles, where the hypersecretion of 
this hormone or CRH by hypophyseal or ectopic tumours leads to adrenal hyperfunction, resulting in hypercortisolism. Conversely, the minority of cases represent ACTH-Independent profiles, where the adrenal cortex releases inappropriately high levels of cortisol, free from any effective hypothalamic-hypophyseal regulation. Additionally, both profiles may be found in the cyclic variant of CS, where due to as of yet unknown reasons, patients exhibit intermittent hypercortisolemia patterns and normal plasma cortisol levels (Velez, Mayberg, \& Ludlam, 2007). Pseudo-Cushing's states have also been described; where hypercortisolemia exists in the absence of tissue alterations within the components of the HHAA, these may often be associated to exacerbations of the physiologic stimuli for glucocorticoid secretion, or be idiopathic (Arnaldi et al., 2009; Chabre, 2018).

Table 1. Causes of Cushing's syndome

\begin{tabular}{lll}
\hline DIAGNOSIS & PrevalencE & FEMALE:MALE RATIO \\
\hline ACTH-Dependent & & \\
Cushing's Disease & $65 \%$ & $3-5: 0-1$ \\
Ectopic ACTH secretion & $7 \%$ & $1: 1$ \\
Ectopic CRH secretion & $<1 \%$ & $1: 1$ \\
\hline ACTH-Independent & & \\
Adrenal adenoma & $18 \%$ & $4: 1$ \\
Adrenal carcinoma & $6 \%$ & $1: 1$ \\
AIMAH $^{\mathrm{a}}$ & $3 \%$ & $1: 1$ \\
PPNAD $^{\mathrm{b}}$ & $1 \%$ & $1: 1$ \\
\hline
\end{tabular}

Causes of Cushing's syndrome $(\mathrm{n}=423)$;

a ACTH-Independent macronodular adrenal hyperplasia;

b Primary pigmented nodular adrenocortical disease.

\section{Diagnostic Protocol}

The diagnostic algorithm for CS entails two phases: an initial stage aimed at evidencing elevated cortisol levels (Figure 1); and a subsequent stage targeted to the identification of the specific cause of the endogenous hypercortisolism, based in the differentiation of pathophysiologic profiles: ACTH-Dependent CS vs ACTH Independent CS (Figure 2) (Lila et al., 2011). 


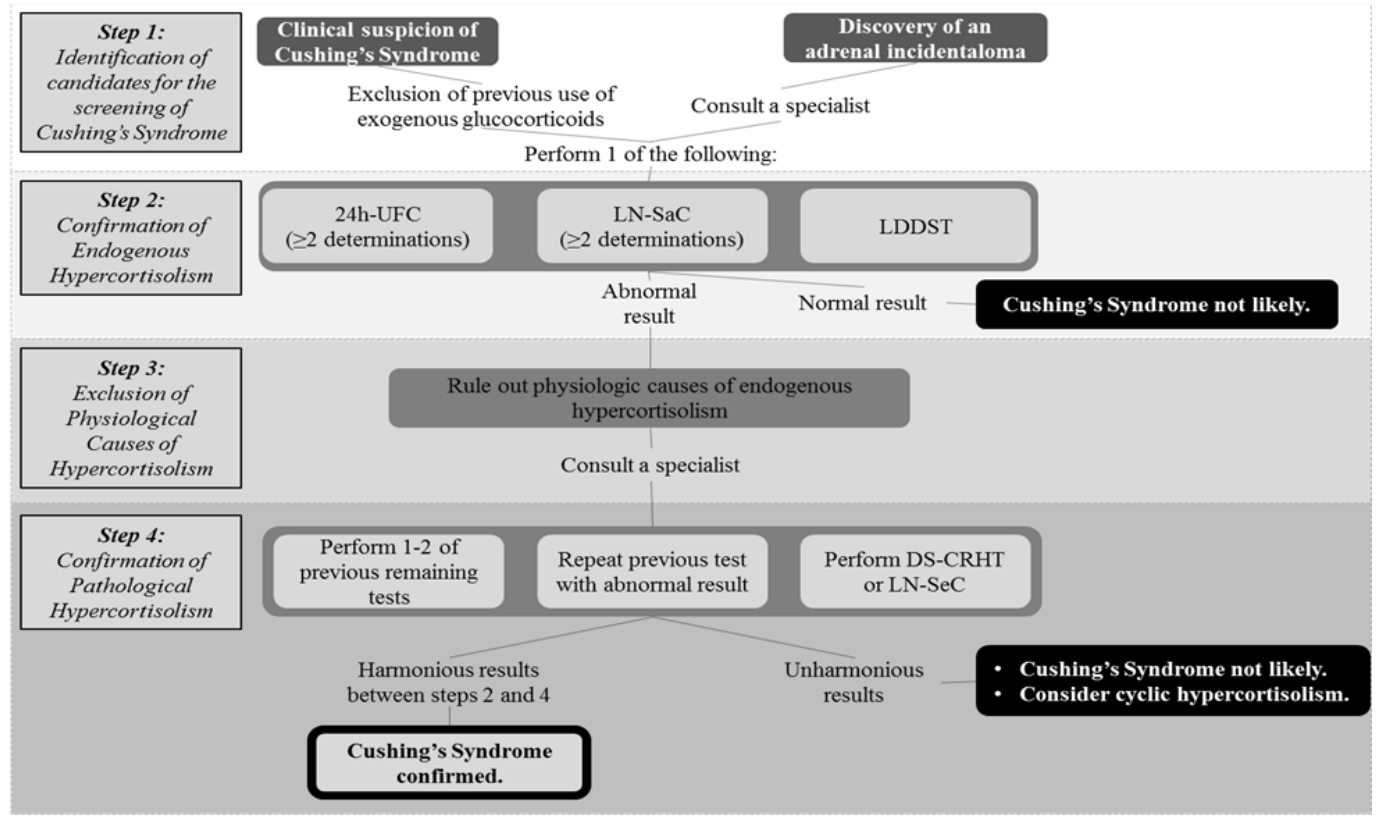

24h-UFC: Daily Urinary Free Cortisol; LN-SaC: Late-Night Salivary Cortisol; LDDST: Low-Dose Dexamethasone Suppression Test; DS-CRHT: Dexamethasone-Suppressed CRH Stimulation Test; LN-SeC: Late-Night Serum Cortisol.

Figure 1. First phase of the diagnosis of Cushing's Syndrome: Identification and confirmation

\begin{tabular}{|c|}
\hline Step 5: \\
Identify the \\
underlying \\
physiopathologic \\
profile \\
\hline
\end{tabular}

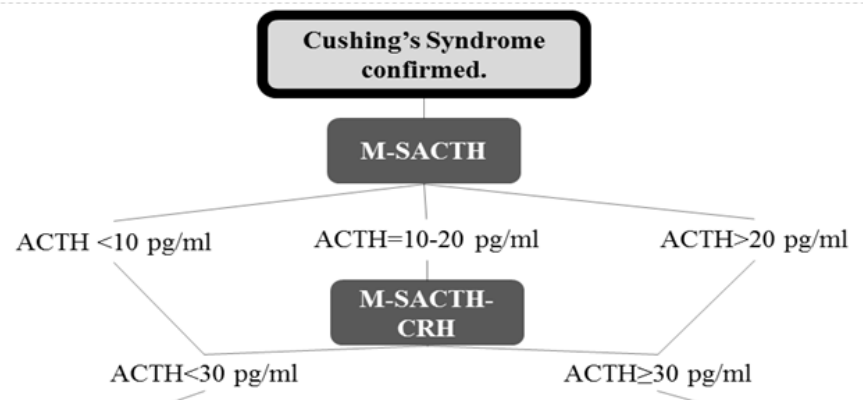

ACTH-Independent

Cushing's Syndrome

ACTH-Dependent

Cushing's Syndrome

\begin{tabular}{|c|}
\hline Step 6: \\
Identify the specific \\
etiology
\end{tabular}

ran

ran

\section{MRI of the}

sella turcica

CT of body

cavities

BIPSS

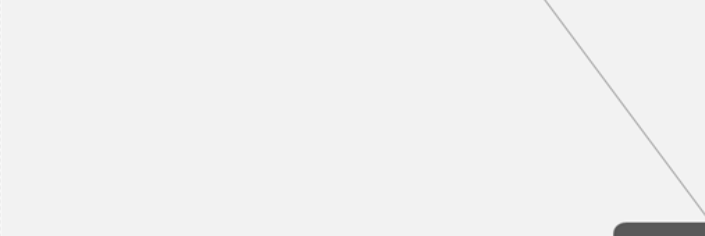

\section{Imaging}

M-SACTH: Morning Serum ACTH; M-SACTH-CRH: Morning Serum ACTH with CRH Stimulation; MRI: Magnetic Nuclear Resonance Imaging; CT: Computed Axial Tomography; BIPSS: Bilateral Inferior Petrosal Sinus Sampling.

Figure 2. Second phase of the diagnosis of Cushing's Syndrome: Differentiation and specification.

\subsection{First Phase of Cushing's Syndrome Diagnosis: Identification and Confirmation}

\subsubsection{Identification of Candidates for the Screening of Cushing's Syndrome}

In the context of primary medical attention, an early clinical suspicion is crucial to the diagnosis of CS, as well as 
an exhaustive inquiry into the subject's history of drug use, to rule out the use of exogenous glucocorticoids (Hopkins \& Leinung, 2005). The clinical signs and symptoms of CS are numerous and based on their relative prevalence in the general population, they may be classified as manifestations with higher or lower discriminatory power for the detection of CS (Table 2), manifestations with low prevalence in the general populations but high prevalence in CS patients are considered highly discriminatory, and vice-versa (Nieman et al., 2008). Particular attention should be paid to criteria such as arterial hypertension and obesity, which are associated with more significant mortality (Giordano et al., 2011); and the presence of osteoporosis in patients younger than 65 years of age, which is very suggestive of CS (Newell-Price, 2009).

Table 2. Clinical manifestations with higher and lower discriminatory power for the diagnosis of Cushing's Syndrome

\begin{tabular}{|c|c|c|c|c|c|c|c|c|c|}
\hline \multirow{4}{*}{ Reference } & \multirow{4}{*}{ Sample } & \multirow{3}{*}{\multicolumn{2}{|c|}{$\begin{array}{l}\text { Manifestatons with } \\
\text { higher discriminatory } \\
\text { power }\end{array}$}} & \multirow{3}{*}{\multicolumn{6}{|c|}{ Manifestations with lower discriminatory power }} \\
\hline & & & & & & & & & \\
\hline & & & & & & & & & \\
\hline & & SIGNS & PCOS & SYMPTOMS & PCOS & SIGNS & PCOS & $\begin{array}{l}\text { ASSOCIATED } \\
\text { CONDITIONS }\end{array}$ & PCOS \\
\hline \multirow{5}{*}{$\begin{array}{l}\text { Boscaro and Arnaldi } \\
\text { (29) }\end{array}$} & \multirow{5}{*}{$\begin{array}{l}423 \\
\text { adults }\end{array}$} & $\begin{array}{l}\text { "Moon face" } \\
\text { and "buffalo } \\
\text { hump" }\end{array}$ & $89 \%$ & $\begin{array}{l}\text { Menstrual } \\
\text { cycle } \\
\text { alterations }\end{array}$ & $69 \%$ & $\begin{array}{l}\text { Central } \\
\text { obesity }\end{array}$ & $97 \%$ & $\begin{array}{l}\text { Arterial } \\
\text { hypertension }\end{array}$ & $76 \%$ \\
\hline & & Easy bruising & $75 \%$ & $\begin{array}{l}\text { Affective } \\
\text { psychiatric } \\
\text { symptoms }\end{array}$ & $55 \%$ & Acne & $56 \%$ & T2DM & $70 \%$ \\
\hline & & Facial plethora & $70 \%$ & $\begin{array}{l}\text { Polydipsia/po } \\
\text { lyuria }\end{array}$ & $10 \%$ & Hirsutism & $56 \%$ & PCOS & $69 \%$ \\
\hline & & $\begin{array}{l}\text { Proximal } \\
\text { muscle } \\
\text { weakness }\end{array}$ & $68 \%$ & & & Edema & $15 \%$ & Osteoporosis & $40 \%$ \\
\hline & & $\begin{array}{l}\text { Purplish skin } \\
\text { striae }\end{array}$ & $64 \%$ & & & & & $\begin{array}{l}\text { Opportunistic } \\
\text { infections }\end{array}$ & $8 \%$ \\
\hline \multirow{2}{*}{$\begin{array}{l}\text { Ilias, } \\
(65)\end{array}$} & \multirow{2}{*}{90 adults } & & & $\begin{array}{l}\text { Cognitive } \\
\text { dysfunction }\end{array}$ & $22 \%$ & $\begin{array}{l}\text { Skin } \\
\text { hyperpigm } \\
\text { entation }\end{array}$ & $19 \%$ & Hypokalemia & $71 \%$ \\
\hline & & & & $\begin{array}{l}\text { Diminished } \\
\text { libido }\end{array}$ & $24 \%$ & & & & \\
\hline $\begin{array}{l}\text { Faggiano, Pivonello } \\
\text { et al. (97) }\end{array}$ & 24 adults & & & & & & & Renal lithiasis & $50 \%$ \\
\hline
\end{tabular}

T2DM: Type 2 Diabetes Mellitus; PCOS: Polycystic Ovary Sydrome.

The clinical picture of CS is widely variable, but it offers vital clues that may orient clinicians towards the etiologic diagnosis at very early stages of the diagnostic protocol. Cutaneous hyperpigmentation is unique to ACTH-dependent variants, and it is more severe in ectopic ACTH secretion syndromes (Paus, 2011), as are hypokalemia and arterial hypertension (Fernández-Rodríguez et al., 2008). On the other hand, bone degeneration, hirsutism and diminished libido are more prominent in ACTH-Independent presentations. Besides, when CS is caused by adrenal carcinoma or paraneoplastic syndromes in ACTH-Dependent variants, clinical manifestations relative to the neoplasia, particularly weight loss, may often mask the expressions of CS (Newell-Price, Bertagna, Grossman, \& Nieman, 2006).

Screening for CS is recommended in patients who present any combination of the signs above and symptoms, especially those with higher discriminatory power; as well as in individuals with adrenal incidentalomas (Zeiger et al., 2009; Lee et al., 2017). Although up to $2 \%$ of cases of T2DM may be a consequence of CS, the screening for 
hypercortisolemia is not indicated for all diabetic patients, unless other features of CS are present (Catargi, Rigalleau, \& Poussin, 2003).

\subsubsection{Confirmation of Endogenous Hypercortisolism}

Once a suspicious case has been identified, three distinct tests may be recommended based on their high sensitivity and specificity: Quantification of daily Urinary Free Cortisol (24h-UFC), Late-Night Salivary Cortisol (LN-SC) and/or the Low-Dose Dexamethasone Suppression Test (LDDST). Although the gold standard is LN-SC, any one of these tests may be performed, and a positive result in any of them confirms hypercortisolism. If a negative result is seen in patients with a severe clinical picture highly suggestive of CS, the chosen test should be repeated or complemented with any of the other two tests (Tsagarakis, Vassiliadi, \& Thalassinos, 2006). The sensitivity and specificity of tests used in the diagnosis of CS are summarized in Table 3 (De Castro \& Moreira, 2007).

Table 3. Screening tests for Cushing's Syndrome: diagnostic criteria, sensitivity and specificity for each test

\begin{tabular}{llll}
\hline Screening test & Criteria & Sensitivity & Specifity \\
\hline Daily Urinary Free Cortisol & 3-fold basal values* & $90-98 \%$ & $45-95 \%$ \\
LDDST w/4 mg DEX in 24 hours & $<1.8 \mu \mathrm{g} / \mathrm{dL}$ & $91-97 \%$ & $87-94 \%$ \\
LDDST w/1 mg DEX overnight & $<1.8 \mu \mathrm{g} / \mathrm{dL}$ & $92-100 \%$ & $92-100 \%$ \\
Late-Night Salivary Cortisol & $<250 \mathrm{ng} / \mathrm{dL}$ & $90-96 \%$ & $96-100 \%$ \\
DEX-Suppressed CRH Test & $<1.4 \mu \mathrm{g} / \mathrm{dL}$ & $100 \%$ & $67-100 \%$ \\
Late-Night Serum Cortisol (Sleep) & $<1.8 \mu \mathrm{g} / \mathrm{dL}$ & $93-100 \%$ & $20-26 \%$ \\
Late-Night Serum Cortisol (Awake) & $<7.5 \mu \mathrm{g} / \mathrm{dL}$ & $96-100 \%$ & $88-100 \%$ \\
\hline
\end{tabular}

*Daily Urinary Free Cortisol normal range: $<80-120 \mu \mathrm{g} / 24 \mathrm{~h}$ or $<220-330 \mathrm{mmol} / 24 \mathrm{~h}$ (Radioimmunoassay);

$<50 \mu \mathrm{g} / 24 \mathrm{~h}$ or $<138 \mathrm{nmol} / 24 \mathrm{~h}$ (High Performance Liquid Chromatography).

LDDST: Low-Dose Dexamethasone Suppression Test; DEX: Dexamethasone; CRH: Cortictropin-Releasing Hormone.

\subsubsection{Daily Urinary Free Cortisol (24h-UFC)}

This test allows the assessment of the fraction of serum cortisol that is filtrated in the kidneys and excreted in urine over a day, regardless of the normal fluctuations of its serum concentrations within a day. Specifically, this test does not quantify any part of the $90 \%$ of total cortisol which is usually bound to transporter plasmatic proteins, but only the fraction that is filtrated in kidneys from the remaining $10 \%$ of total cortisol, which is not protein-bound (Kola \& Grossman, 2005).

Sample recollection begins with the second micturition of the day, and all subsequent urinations must be collected throughout the day. The final recollection should be the first micturition of the second day. Results from this test are widely variable due to the complex interactions between cortisol and its plasmatic transporter proteins, from which it may be readily displaced by other steroidal hormones and various drugs and clinical conditions (Figure 3) (34). Therefore, hypercortisolism is only confirmed if figures 3-4 times higher than the superior reference values are obtained in at least 2 determinations (Findling \& Raff, 2005). This test must be accompanied by renal functionalism tests, primarily total urinary volume and urinary creatinine. False positive results may arise due to cross-reactivity with cortisol metabolites in commercially available assays; or under conditions such as pregnancy, alcoholism and hypervolemia (Sakihara et al., 2010). 


\begin{tabular}{|c|c|c|c|}
\hline \multicolumn{4}{|c|}{ Drugs that may falsely elevate cortisol levels } \\
\hline Mechanism & Drug & Disease or clinical condition & Reference \\
\hline \multirow{3}{*}{$\begin{array}{c}\text { Increase in synthesis } \\
\text { of Corticosteroid- } \\
\text { Binding Protein } \\
\text { (CBG). }\end{array}$} & Estrogens & $\begin{array}{l}\text { Hormonal Replacement } \\
\text { Therapy / Contraceptives }\end{array}$ & (Edwards \& Mills, 2008) \\
\hline & Mitotane & Adrenocortical carcinoma & (Nader; et al., 2006) \\
\hline & Morphine & Cancer / Pain & (Nock, Wich \& Cicero, 1997) \\
\hline \multirow{3}{*}{$\begin{array}{l}\text { Displace cortisol from } \\
\text { CBG binding site. }\end{array}$} & Carbamazepine & Seizures / Neuropathic pain & (Tiong \& Falhammar; 2009) \\
\hline & Digoxin & $\begin{array}{l}\text { Chronic Heart Failure + } \\
\text { atrial fibrillation }\end{array}$ & $\begin{array}{c}\text { Makras, Toloumis, } \\
\text { Papadogias, Kaltsas \& } \\
\text { Besser, 2006) }\end{array}$ \\
\hline & Fenofibrate & High tryglicerides levels & (Meikle, et al., 2003) \\
\hline \multicolumn{4}{|c|}{ Drugs that modify glucocorticoid metabolism } \\
\hline \multirow{10}{*}{$\begin{array}{c}\text { Accelerate DEX } \\
\text { metabolism } \\
\text { (CYP3A4 induction) }\end{array}$} & Carbamazepine & Seizures / Neuropathic pain & (Ma, et al., 2005) \\
\hline & Clotrimazole & Fungal infection & (Luo, et al., 2002) \\
\hline & Ethosuximide & Absence Seizures & $\begin{array}{c}\text { Sarver, Bachmann, Zhu \& } \\
\text { Klis, 1998) }\end{array}$ \\
\hline & Phenobarbital & Seizures & (Maronpot, et al., 2010) \\
\hline & Phenytoin & Seizures & (Rüegg, 2002) \\
\hline & Pioglytazone & Type 2 diabetes mellitus & (Ripp, et al., 2006) \\
\hline & Primidone & Seizures & (Perucca, 2006) \\
\hline & Rifapentine & Tuberculosis & $\begin{array}{l}\text { Rae, Johnson, Lippman \& } \\
\text { Flockhart, 2001) }\end{array}$ \\
\hline & Rifampin & $\begin{array}{l}\text { Tuberculosis and others } \\
\text { infections }\end{array}$ & $\begin{array}{c}\text { Rae, Johnson, Lippman \& } \\
\text { Flockhart, 2001) }\end{array}$ \\
\hline & Verapamil & $\begin{array}{l}\text { Coronary ischemic disease } \\
\text { Supraventricular tachycardia } \\
\text { Migraine prophylaxis }\end{array}$ & (Fahmi, et al., 2001) \\
\hline \multirow{7}{*}{$\begin{array}{c}\text { Decelerate DEX } \\
\text { metabolism } \\
\text { (CYP3A4 inhibition) }\end{array}$} & Aprepitant & $\begin{array}{l}\text { Dhemotherapy-induced } \\
\text { nausea and vomiting }\end{array}$ & (De Jonge, et al, 2005) \\
\hline & Cimetidine & Peptic ulcer disease & (Scheinfeld, 2003) \\
\hline & Diltiazem & $\begin{array}{l}\text { Coronary ischemic disease } \\
\text { Migraine prophylaxis }\end{array}$ & (Jones, et al.,1999) \\
\hline & Fluoxetine & $\begin{array}{l}\text { Depression and other mental } \\
\text { disease }\end{array}$ & $\begin{array}{c}\text { (Hemeryck \& Belpaire, } \\
\text { 2002) }\end{array}$ \\
\hline & Itraconazole & Fungal infection & $\begin{array}{l}\text { (Isoherranen, Kunze,, Allen, } \\
\text { Nelson \&, Thummel, 2004) }\end{array}$ \\
\hline & Nefazodone & Depression & (DeVane, et al., 2004) \\
\hline & Ritonavir & $\begin{array}{l}\text { Human Inmunodeficiency } \\
\text { Virus infection }\end{array}$ & (Zeldin \& Petruschke, 2004) \\
\hline
\end{tabular}

Figure 3. Drugs that interfere with tests performed for the diagnosis of Cushing's Syndrome

\subsubsection{Low-Dose Dexamethasone Suppression Test (LDDST)}

This procedure evaluates the adequate functioning of the feedback mechanisms in the HHAA by interfering with the exogenous oral administration of dexamethasone. If cortisol secretion is lowered, the functional integrity of the HHAA is corroborated; whereas serum cortisol concentrations $\geq 1.8 \mu \mathrm{g} / \mathrm{dl}$ following dexamethasone administration reflect the dysregulation of the HHAA and suggest CS (Esfahanian \& Kazemi, 2010).

LDDST can be carried out in two different manners: $4 \mathrm{mg}$ of dexamethasone may be administrated in equal fractions throughout 24 hours, or $1 \mathrm{mg}$ may be given at night between 11-12 pm. In both cases, serum cortisol is measured the following morning, between 8-9 am (Vilar et al., 2007). The second method is more broadly recommended because it is more easily accomplished and renders a better cost-benefit profile (Findling, Raff \& Aron, 2004). Similarly to $24 \mathrm{~h}$-UFC, this procedure is susceptible to returning false positives under the same altering factors, but it is more thoroughly distorted by the consumption of drugs that induce dexamethasone metabolism (Figure 3) (Klose et al., 2009). 


\subsubsection{Late-Night Salivary Cortisol (LN-SaC)}

The principle of this test is to demonstrate alterations in the circadian cycle of cortisol secretion, normally serum cortisol and ACTH levels reach their peak in the morning, around $9 \mathrm{am}$; and their nadir during the night, around 11 pm. Therefore, elevated cortisol levels in this point are evidence of circadian dysregulation of the HHAA (Dickmeis, 2009). Although the cut-off point for CS change according to each particular assay, LN-SaC values $\geq 250 \mathrm{ng} / \mathrm{dl}$ are universally regarded as diagnostic (Vilar et al., 2007). Sample-taking may be directly realised in test tubes or by chewing cotton pieces which must be centrifuged afterwards (Lavalle-González et al., 2011). This test requires at least two determinations, and it may be falsely elevated due to haemorrhages or lesions in the oral cavity, or stress due to wakefulness at late night (Kalman \& Grahn, 2004).

\subsubsection{Exclusion of Physiological Causes of Hypercortisolism}

If the previous procedures confirm hypercortisolism, the exclusion of its physiological causes is recommended (Table 4), as they may be conditioning chronic hypersecretion of this hormone in the absence of histologic alterations within the components of the HHAA (Nieman et al., 2008). A detailed examination of the psychobiological habits and mental state of studied patients may be particularly revealing in this respect, with alcoholism (Besemer, Pereira, \& Smit, 2011) and depressive states (Carroll et al., 2007) being the most frequent causes.

Table 4. Conditions associated with physiologic hypercortisolism

\begin{tabular}{ll}
\hline Very high risk of hypercortisolism & High risk of hypercortisolism \\
\hline Pregnancy & Physical or psychologic stress \\
Depression and other psychiatric illnesses & Malnutrition \\
Alcoholism & Chronic intense exercise \\
Obesity & \\
Poorly controlled diabetes mellitus & \\
\hline
\end{tabular}

\subsubsection{Confirmation of Pathological Hypercortisolism}

If physiological causes of hypercortisolism can be excluded, the result from the chosen test in the first step must be complemented with at least two other tests, of which outcomes should be assessed by an endocrinologist. The general recommendation is to complete the initial test triad (24h-UFC, LDDST, and LN-SaC), but additional alternatives are available for certain specific populations (Elamin et al., 2008):

\subsubsection{Dexamethasone-Suppressed Corticotropin-Releasing Hormone Test (DS-CRHT)}

This procedure is suitable in patients where $24 \mathrm{~h}-\mathrm{UFC}$ or $\mathrm{LN}-\mathrm{SaC}$ tests return conflictive results. However, several studies question its usefulness over simple LDDST (Albiger, Scaroni, \& Mantero, 2007). This test entails the oral administration of $0.5 \mathrm{mg}$ of dexamethasone every 6 hours over 48 hours, and then $1 \mu \mathrm{g} / \mathrm{kg}$ of intravenous CRH 2 hours after the final doses of dexamethasone. Serum cortisol is measured 15 minutes later: Levels $\geq 1.4 \mu \mathrm{g} / \mathrm{dl}$ suggest CS. Its sensitivity and specificity may be altered by the same factors that disturb LDDST results (Gatta et al., 2007).

\subsubsection{Late-Night Serum Cortisol (LN-SeC)}

This test is recommended in patients who arise a clinical suspicion of CS, but return normal results in 24h-UFC and LDDST. Cortisol is measured between 11-12 pm; this requires overnight hospitalisation and sample taking during sleep, which requires trained personnel; therefore, its indication is restricted. Patients must remain in a calm environment, fasting and at absolute rest starting at least 2 hours before the first sample is extracted. If samples are planned to be taken during sleep, catheters should be inserted at least 1 hour before the sample is taken. Serum cortisol levels $\geq 1.8 \mu \mathrm{g} / \mathrm{dl}$ during sleep or $\geq 7.5 \mu \mathrm{g} / \mathrm{dl}$ in wakefulness are suggestive of CS (Nieman et al., 2008).

If results from the initial procedures in Step 2 are concordant with those from Step 4, the diagnosis of CS is established. Unharmonious results between these steps usually rule out CS, although a small proportion of these cases may represent cyclic hypercortisolism, in which case the recommendation is to repeat all laboratory testing to rule out potential analytical errors (Isidori et al., 2006). 


\subsection{Second Phase of Cushing's Syndrome Diagnosis: Differentiation and Specification}

\subsubsection{Identify the underlying pathophysiologic profile: ACTH Dependence vs Independence}

The distinction of the implied physiopathology is crucial for the selections of a therapeutic plan. Morning serum ACTH determination (M-SACTH) around 9 am is a useful tool in the pathophysiologic characterisation of CS (Findling \& Raff, 2006). Elevated ACTH levels $>20 \mathrm{pg} / \mathrm{ml}$ classify cases as ACTH-Dependent, whereas concentrations $<10 \mathrm{pg} / \mathrm{ml}$ categorise them as ACTH-Independent. Intermediate results between $6-14 \mathrm{pg} / \mathrm{ml}$ are equivocal or suggest Pseudo-Cushing's states or subclinical CS (Raff \& Findling, 2003). If such values are returned, the repetition of the test with added CRH stimulation (M-SACTH-CRH) is recommended. In this procedure, results $<30 \mathrm{pg} / \mathrm{ml}$ exclude the presence of ACTH-Dependent CS (Chiodini, 2011).

\subsubsection{Identify the Specific Aetiology}

\subsubsection{ACTH-Dependent CS: Cushing's Disease vs Ectopic CRH/ACTH Secretion Syndromes}

Traditionally, the High-Dose Dexamethasone Suppression Test, Morning Serum ACTH with Desmopressin Stimulation and M-SACTH-CRH were used in the differentiation between etiologies of ACTH-Dependent CS. However, the pre-test probability for a hypophyseal origin to the case is $>80 \%$ and up to $>90 \%$ in women. Therefore, since none of these tests reaches a specificity $>90 \%$, which is the pre-test probability for $\mathrm{CD}$, the continuity in its use is no longer justified (Deipolyi et al., 2012).

Thus, Nuclear Magnetic Resonance Imaging (MRI) of the sella turcica represents the next step in diagnosis, the typical lesion in $\mathrm{CD}$ is a microadenoma $(<10 \mathrm{~mm}$ in width) of lateral localization within the adenohypophysis, which is hypointense in the T1 phase, and usually does not uptake contrast material (Ilias, et al., 2005). Additionally, incidentalomas $<5 \mathrm{~mm}$ found in the sella turca may be assumed as the probable cause of CS in patients with suggestive clinical findings, representing a fortuitous shortcut in the diagnostic protocol (Gutiérrez-Restrepo, Latorre-Sierra, \& Campuzzano, 2009)

Nevertheless, in $30-50 \%$ of cases, no lesions may be visualised through MRI, rendering Computerized Tomography (CT) of the neck, thorax, abdomen, and pelvis the next step in diagnosis (Shahani, Nudelman, Nalini, Kim, \& Samson, 2010) in search of ectopic CRH/ACTH secretion foci. If no tumours are discovered or symptoms are inconclusive, Bilateral Inferior Petrosal Sinus Sampling (BIPSS) is indicated. Due to the risks associated with its invasiveness, it is reserved for patients where no tumours have been found through the previous imaging techniques (Bhansali et al., 2009).

This procedure involves the catheterisation of both petrosal sinuses, through which $10 \mu \mathrm{g}$ of desmopressin or 1 $\mu \mathrm{g} / \mathrm{kg}$ of CRH are administered. Serum ACTH levels are determined from a peripheral vein and both sinuses five times from each point: The first time 1 minute before the administration of desmopressin or $\mathrm{CRH}$, a second time simultaneous to the infusion, and then three successive times at 3,5 and 10 minutes after the administration. Central-peripheral ACTH ratios $\geq 3$ suggest $C D$ as they demonstrate a significantly higher secretion of hypophyseal ACTH when compared to potential ectopic secretion foci in the rest of the organism. The incidence of false negatives has been attributed to inexpert catheterisation, anomalous venous drainage, hypoplasia of the venous sinuses and other anatomic variants. Also, BIPSS has been suggested for the determination of laterality of adenomas within the hypophysis. A bisinusal ACTH ratio $\geq 1.4$ for a given sinus indicates the ipsilateral presence of a corticotropic hypophyseal microadenoma with 70-78\% specificity (Utz \& Biller, 2007). BIPSS is a procedure that must be performed in specialized centers where there are a radiologist and neurosurgeon experienced in the handling of potential complications associated to this procedure (venous sinus thrombosis, cranial nerve paralysis, brainstem vascular damage) However, if BIPSS is performed correctly has a high sensitivity (>95\%) and specificity for CD and diagnostic accuracy $>9$ (Wagner-Bartak et al., 2017). If ectopic CRH/ACTH secretion syndromes are suspected after BIPSS assessment, exhaustive imaging of all body cavities is required, including MRI, CT and scintigraphy with octreotide to localise the ectopic source (Pelosof \& Gerber, 2010).

The main nuclear tests used in CS diagnosis are octreotide scan, FDG positron emission tomography (PET), and 68Ga-somatostatin PET / CT receptor, which could detect up to $80 \%$ of tumours not identified with conventional imaging techniques. The Octeotride scan or "Octreoscan" uses a somatostatin's synthetic analogue to detect neuroendocrine tumours secreting ectopic $\mathrm{ACTH}$, among which, gastroenteropancreatic tumours, adrenal medulla, bronchial carcinoids, among others. Pentetreotide is another molecule used as a conjugated diethylenetriaminepentaacetic acid of octreotide, which is combined with ${ }^{111}$ In. Likewise, somatostatin analogues could be combined with ${ }^{68} \mathrm{Ga}$ for PET, which would offer a better pharmacokinetic and visualisation profile. A recent systematic review comparing conventional imaging techniques with those of nuclear medicine in the determination of ectopic Cushing syndrome, shows an improvement in diagnostic sensitivity after applying 
nuclear medicine techniques when the identification of the tumour is challenging, and both ${ }^{111}$ In-Pentetreotide Scintigraphy and FDG-PET were useful, while ${ }^{68} \mathrm{Ga}$-SSTR-PET / CT offers the highest sensitivity but the high cost limit its use (Isidori, et al., 2015; Bansal, El Asmar, Selman, \& Arafah, 2015).

Nonetheless, a single positive imaging study may represent a falsely positive result, whereas more than one positive study confirms true findings. Hence, all three imaging techniques should always be performed in this scenario (Pacak et al., 2004). Ectopic CRH/ACTH secretion foci are most frequently located within small cell bronchogenic carcinomas, followed by pheochromocytomas, and thymus, pancreas and medullary thyroid carcinomas (Ballay et al., 2012).

\subsubsection{ACTH-Independent CS: Differentiation of Specific Etiologies}

Imaging techniques are the cornerstone of the distinction of etiologies of ACTH-Independent CS. CT of adrenal glands are often sufficient to accurately characterize lesion phenotypes as benign adenomas or malignant carcinomas based on classical criteria, such as size $(<6 \mathrm{~cm}$ or $\geq 6 \mathrm{~cm}$, respectively), mass homogeneity and border regularity. Moreover, areas of necrosis and haemorrhage are highly suggestive of malignancy (Arnold, Reed, \& Burt, 2003). Unenhanced attenuation values $<10 \mathrm{HU}$ are indicative of a benign lesion (Caoili et al., 2002); whereas in contrast-enhanced scans, a cut-off point of $37.5 \%$ for relative percentage washout detects malignant lesions with $100 \%$ sensitivity and $95 \%$ specificity (Blake et al., 2006).

On the other hand, MRI may be used as a complementary test. Adenomatous lesions exhibit homogenous signal intensity on all MRI pulse sequences, with relative isointensity to liver on T2-weighted images, with a signal intensity index $>20 \%$. Meanwhile, adrenal carcinoma returns a heterogeneous signal, being hypointense on T1-weighted MRI and hyperintense on T2-weighted images (Blake, Cronin, \& Boland, 2010). Primary pigmented nodular adrenocortical disease (PPNAD) is a congenital entity characterised by slight adrenal hypertrophy, observable on CT, with the conservation of glandular architecture and nodules of $0.5-2 \mathrm{~cm}$ in width. Alterations are always bilateral, and as an unusual analytical feature, patients often show a paradoxical rise in cortisol levels after performing LDDST (Ganesh et al., 2008).

ACTH-Independent Macronodular Adrenal Hyperplasia (AIMAH) is also a congenital disease, where adrenal tissue expresses illegitimate $G$ protein-coupled receptors, including ectopic receptors for gastric inhibitory polypeptide (GIP), luteinizing hormone (LH), human chorionic gonadotropin (h-CG), catecholamines and serotonin. CT reveals adrenal hypertrophy and loss of its tissue configuration, as well as nodules of up to $5 \mathrm{~cm}$ in width (Lacroix, 2009; Boente-Varela, Díaz-Pérez, \& Miguel-Novoa, 2005). Furthermore, laboratory testing protocols have been designed for the identification of the specific receptor and hormone implied in each case (Louiset, 2008; Nieman, 2018).

\section{Diagnosis of Cushing's Syndrome in Special Populations}

\subsection{Pregnant Women}

Albeit scarce, reports of CS in pregnant women have been documented (Kita, Sakalidou, Saratzis, Ioannis, \& Avramidis, 2007). This coexistence translates into a higher risk for maternal and fetal complications, including gestational diabetes and hypertensive states, as well as prematurity, fetal death and abortion. Although the physiology of the HHAA remains unaltered during the first trimester of pregnancy, it is modified throughout the second and third trimesters. Serum cortisol concentrations are higher than in non-pregnancy during their late-night nadir within their circadian rhythm of secretion. Likewise, dexamethasone suppression of the HHAA is diminished. As a result, there is more probability for false positives in tests such as $24 \mathrm{~h}-\mathrm{UFC}$ and LDDST. Moreover, no diagnostic cut-off points have been determined for $\mathrm{LN}-\mathrm{SaC}$ or $\mathrm{LN}-\mathrm{SeC}$ in pregnant women (Lindsay, Jonklaas, Oldfield, \& Nieman, 2005).

\subsection{Childrens and Adolescents}

Pediatric patients and CS are also infrequently associated. The mean age of presentation is 14.1 years, and it is more often seen in male. In this case, the ACTH-Independent varieties are rare, and up to $80 \%$ of cases are due to CD (Savage, Chan, Grossman, \& Storr, 2008). Specific signs of CS are unique to pediatric patients, including virilisation of genitalia in females, accelerated virilisation in males, early or delayed onset of puberty, and weight gain with a deceleration of height gain. These manifestations generate a severe impact in the integral development of affected children, since they are often not reversible, particularly concerning weight and height disturbances. Although the diagnostic algorithm is similar, BIPSS is only recommended in exceptional cases due to the higher risk of complications in these patients and the extremely low incidence of ectopic CRH/ACTH secretion syndromes in this demography (Chan, Storr, Grossman, \& Savage, 2007). 


\section{Therapeutic Principles in Cushing's Syndrome}

Surgery is the mainstay therapeutic alternative in most ACTH-Dependent presentations of CS, oriented to the resection of the tumoral mass in question. This management offers a quick improvement of clinical manifestations, with a recurrence risk of $5-10 \%$ in 5 years, and of $20 \%$ in 10 years after the procedure (Rizk, Honegger, Milian, \& Psaras, 2012). For recurrent or persistent cases of CD, after having exhausted surgical options, radiotherapy is a well-established second-line treatment. Nevertheless, this option implies a longer period of latency until remission of signs and symptoms, three years on average (Castinetti, Régis, Dufour, \& Brue, 2010). The main complication inherent to both treatments is hypopituitarism, with a risk of $8.7-53 \%$ for surgical resection and $50-60 \%$ for radiotherapy (Biller et al., 2008). For ACTH-Independent CS cases, the most utilised treatment is bilateral adrenalectomy, which offers immediate improvement of clinical manifestations. However, the obvious disadvantage of this procedure is the subsequent permanent hypoadrenalism, which requires lifetime hormone replacement therapy (Chow et al., 2008). Medical therapy plays a secondary role to the previous alternatives in the management of CS, where it is used in severe cases of hypercortisolism to lower anaesthetic risk for a given surgical procedure or to diminish clinical afflictions during the latency period for remission in radiotherapy (Mancini, Porcelli \& Giustina, 2010 and Hinojosa-Amaya, Cuevas-Ramos, \& Fleseriu, 2019).

Drugs used in the medical management of CS can be classified in two categories: Adrenal enzyme inhibitors and neuromodulators. The first group includes molecules such as ketoconazole, metyrapone, aminogluthetimide, mitotane and etomidate, which act by blocking distinct steps of corticosteroid synthesis pathways in the adrenal glands. Nonetheless, they boast extensive adverse effect profiles, mainly because they can block steroidogenesis systemically, which translates into numerous endocrine disturbances (Gross, Mindea, Pick, Chandler, \& Batjer, 2007). On the other hand, neuromodulators include dopaminergic agonists and somatostatin analogues, which act by inhibiting ACTH secretion from the hypophysis. Although clashing evidence is documented regarding the effectiveness of these drugs in the management of CS; pasireotide, a somatostatin analogue, has been recently approved for the etiological treatment of CD in patients who are not suitable surgery candidates (Colao et al., 2012; Cuevas-Ramos, Lim, \& Fleseriu, 2016). Currently, clinical trials are being carried out to evaluate the effectiveness of osilodrostat and levoketoconazole as inhibitors of steroidogenesis as more prominent objectives in pharmacotherapy area (Feelders, Newell-Price, Pivonello, Nieman, Hofland, \& Lacroix, 2019).

\section{Recommendations}

Due to the severe morbidity caused by CS and the drastic impoverishment it implies on the quality of life of affected patients, the diagnosis must be timely and effectively (Vasquez et al., 2018; Acosta-Martinez, 2018). Principal clinical manifestations such as "moon face", "buffalo hump" and purplish skin striae deserve more considerable attention from clinicians and should awake suspicion of CS. From that point, it is indispensable to preserve a logical plan of action in diagnosis process (Figure 3); especially in the laboratory assessment phase to successfully and efficiently ascertain the underlying cause of the disorder. This differential diagnosis requires a thorough knowledge of adrenal physiology and pathology for the correct selection, application and interpretation of all tests and procedures which may be necessary, which will, in turn, render satisfactory diagnostic results.

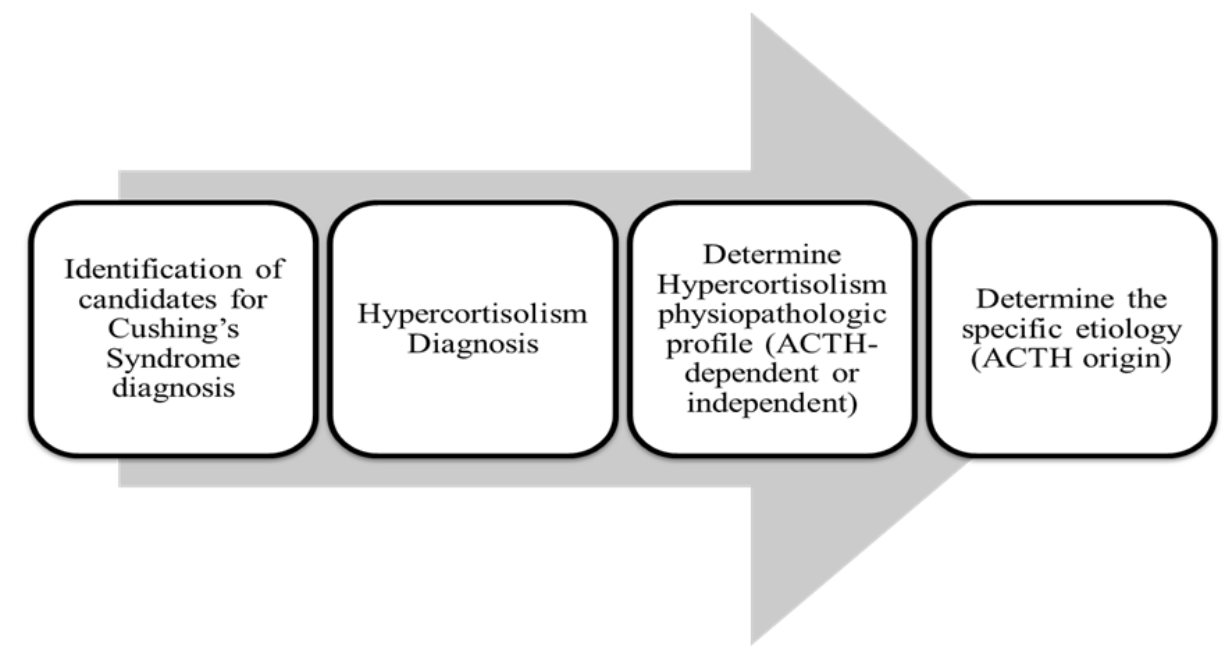

Figure 4. Simplified diagnosis flowchart for Cushing's Syndrome 


\section{Competing Interests Statement}

The authors declare that there are no competing or potential conflicts of interest.

\section{References}

Abegunde, D., \& Anderson, S. (2006). An estimation of the economic impact of chronic noncommunicable diseases in selected countries. WHO. Retrieved from: http://www.who.int/chp/working_paper_growth\%20model29may.pdf

Acosta-Martínez, J., Obesidad y aterosclerosis, Bermúdez-Pirela, V., \& Herazo-Beltrán, Y. (Ed.). Aspectos básicos en obesidad. (pp.60-70). Barranquilla, Colombia. Ediciones Universidad Simón Bolívar. Retrieved from http://bonga.unisimon.edu.co/bitstream/handle/20.500.12442/2273/aspectosbasicosenobesidad.pdf?sequenc $\mathrm{e}=9$ \&isAllowed $=\mathrm{y}$

Albiger, N. M., Scaroni, C. M., \& Mantero, F. (2007). Cyclic Cushing's Syndrome: An Overview. Arq Bras Endocrinol Metab, 51(8), 1253-60.

Albright, F. (1944). Proceedings of the thirty-sixth annual meeting of the American Society for Clinical Investigation held in Atlantic City, NJ, May 8, 1944. J Clin Invest, 23(6), 921-952. https://doi.org/10.1172/JCI101568

Arnaldi, G., Tirabassi, G., Papa, R., Furlani, G., Trementino, L., ... Boscaro, M. (2009). Human corticotropin releasing hormone test performance in the differential diagnosis between Cushing's disease and pseudo-Cushing state is enhanced by combined ACTH and cortisol analysis. Eur J Endocrinol, 160(6), 891-8. https://doi.org/10.1530/EJE-09-0125

Arnaldi, G., Mancini, T., Polenta, B., \& Boscaro, M. (2004). Cardiovascular risk in Cushing's syndrome. Pituitary, 7(4), 253-6. https://doi.org/10.1007/s11102-005-1172-7

Arnold, D. T., Reed, J. B., \& Burt, K. (2003). Evaluation and management of the incidental adrenal mass. Proc (Bayl Univ Med Cent), 16(1), 7-12.

Aron, D. C. (2005). Cushing's syndrome from bedside to bench and back: a historical perspective. Endocrinol Metab Clin North Am, 34(2), 257-69. https://doi.org/10.1016/j.ecl.2005.01.011

Baid, S. K., Rubino, D., Sinaii, N., Ramsey, S., Frank A., \& Nieman, L. K. (2009). Specificity of screening tests for Cushing's syndrome in an overweight and obese population. $J$ Clin Endocrinol Metab, 94(10), 3857-6. https://doi.org/10.1210/jc.2008-2766

Ballav, C., Naziat, A., Mihai, R., Karavitaki, N., Ansorge, O., \& Grossman, A.B. (2012). Mini-review: pheochromocytomas causing the ectopic ACTH syndrome. Endocrine, 42(1), 69-73. https://doi.org/10.1007/s12020-012-9646-7

Bansal ,V., El Asmar, N., Selman, W. R., \& Arafah, B. M. (2015). Pitfalls in the diagnosis and management of Cushing's syndrome. Neurosurg Focus, 38(2), E4. https://doi.org/10.3171/2014.11.FOCUS14704

Belmaker, R. H., \& Agam, G. (2008). Major Depressive Disorder. $N$ Engl J Med, 358, 55-68. https://doi.org/10.1056/NEJMra073096

Besemer, F., Pereira, A. M., \& Smith, J. W. (2011). Alcohol-induced Cushing syndrome. Hypercortisolism caused by alcohol abuse. Neth J Med, 69(7), 318-23.

Beuschlein, F., \& Hammer, G. D. (2002). Ectopic pro-opiomelanocortin syndrome. Endocrinol Metab Clin North Am, 31(1), 191-234.

Bhansali, A., Walia, R., Rana, S. S., Dutta, P., Radotra, B. D., Khandelwal, N., \& Bhadada, S. K. (2009). Ectopic Cushing's syndrome: experience from a tertiary care centre. Indian J Med Res, 129(1), 33-41.

Biller, B.M., Grossman, A.B., Stewart, P.M., Melmed, S., Bertagna, X., Bertherat, J.,... Boscaro, M. (2008). Treatment of adrenocorti-cotropin- dependent Cushing's syndrome: a consensus statement. J Clin Endocrinol Metab, 93, 2454-62. https://doi.org/10.1210/jc.2007-2734

Bishop, P.M.F. \& Close, H.G. (1932). A case of basophil adenoma of the anterior lobe of the pituitary: "Cushing's syndrome". Johns Hopkins Hosp Bull, 50,137-95.

Blake, M. A., Cronin, C. G., \& Boland, G. W. (2010). Adrenal Imaging. AJR Am J Roentgenol, 194(6), 1450-60. https://doi.org/10.2214/AJR.10.4547

Blake, M. A., Kalra, M. K., Sweeney, A. T., Lucey, B. C., Maher, M. M., Sahani, D. V., ... Boland, G.W. (2006). 
Distinguishing benign from malignant adrenal masses: multi-detector row CT protocol with 10-minute delay. Radiology, 238(2), 578-85. https://doi.org/10.1148/radiol.2382041514

Boente-Varela, R., Díaz-Pérez, A., \& Miguel-Novoa, P. (2005). Síndrome de Cushing debido a hiperplasia suprarrenal macronodular independiente de ACTH tratado mediante adrenalectomía unilateral: dos casos. Endocrinol Nutr, 52, 564-8. https://doi.org/10.1016/S1575-0922(05)71065-2

Boscaro, M., \& Arnaldi, G. (2009). Approach to the patient with possible Cushing's syndrome. J Clin Endocrinol Metab, 94(9), 3121-31. https://doi.org/10.1210/jc.2009-0612

Caoili, E. M., Korobkin, M., Francis, I. R., Cohan, R. H., Platt, J. F., Dunnick, N. R., \& Raghupathi, K.I. (2002). Adrenal masses: characterization with combined unenhanced and delayed enhanced CT. Radiology, 222(3), 629-33. https://doi.org/10.1148/radiol.2223010766

Carroll, B.J., Cassidy, F., Naftolowitz, D., Tatham, N.E., Wilson, W.H., Iranmanesh, A., Liu, P.Y. \& Veldhuis, J. D. (2007). Pathophysiology of hypercortisolism in depression. Acta Psychiatr Scand Suppl, 433, 90-103. https://doi.org/10.1111/j.1600-0447.2007.00967.x

Castinetti, F., Régis, J., Dufour, H., \& Brue, T. (2010). Role of stereotactic radiosurgery in the management of pituitary adenomas. J Clin Endocrinol Metab, 6, 214-23. https://doi.org/10.1038/nrendo.2010.4

Catargi, B., Rigalleau, V., Poussin A., Ronci-Chaix, N., Bex, V., Vergnot, V., ... Tabarin, A. (2003). Occult Cushing's syndrome in type-2 diabetes. $J$ Clin Endocrinol Metab, 88, 5808-13. https://doi.org/10.1210/jc.2003-030254

Chabre, O. (2018). The difficulties of pseudo-Cushing's syndrome (or "non-neoplastic hypercortisolism"). Ann Endocrinol (Paris), 79(3), 138-145. https://doi.org/10.1016/j.ando.2018.04.017.

Chan, L. F., Storr, H. L., Grossman, A. B., \& Savage, M. O. (2007). Pediatric Cushing's syndrome: clinical features, diagnosis, and treatment. Arq Bras Endocrinol Metabol, 51(8), 1261-71.

Chiodini, I. (2011). Clinical review: Diagnosis and treatment of subclinical hypercortisolism. J Clin Endocrinol Metab, 96(5), 1223-36. https://doi.org/10.1210/jc.2010-2722

Chow, J. T., Thompson, G. B., Grant, C. S., Farley, D. R., Richards, M. L., \& Young, W. F., Jr (2008). Bilateral laparoscopic adrenalectomy for corticotrophin-dependent Cushing's syndrome: a review of the Mayo Clinic experience. Clin Endocrinol (Oxf), 68, 513-9. https://doi.org/10.1111/j.1365-2265.2007.03082.x

Clayton, R. N. (2010). Mortality in Cushing's Disease. Neuroendocrinology, 92 (Suppl. 1), 71-76. https://doi.org/10.1159/000315813

Clayton, R. N., Raskauskiene, D., Reulen, R. C., \& Jones, P. W. (2011). Mortality and morbidity in Cushing's disease over 50 years in Stoke-on-Trent, UK: audit and meta-analysis of literature. J Clin Endocrinol Metab, 96(3), 632-42. https://doi.org/10.1210/jc.2010-1942

Colao, A., Petersenn, S., Newell-Price, J., Findling, J.W., Gu, F., Maldonado, M., Pasireotide B2305 Study Group. (2012). A 12-month phase 3 study of pasireotide in Cushing's disease. $N$ Engl J Med, 366(10), 914-24. https://doi.org/10.1056/NEJMoa1105743

Cuevas-Ramos, D., Lim, D., \& Fleseriu, M. (2016). Update on medical treatment for Cushing's disease. Clin Diabetes Endocrinol, 2:16. https://doi.org/10.1186/s40842-016-0033-9.

Cushing, H. (1913). The Pituitary Body and Its Disorders. Ann Surg, 57(1), 137-142.

De Castro, M. \& Moreira, A.C. (2007). Screening and Diagnosis of Cushing's Syndrome. Arq Bras Endocrinol Metab, 51(8), 1191-1198.

de Jonge, M. E., Huitema, A. D., Holtkamp, M. J., van Dam, S. M., Beijnen, J. H., \& Rodenhuis, S. (2005). Aprepitant inhibits cyclophosphamide bioactivation and thiotepa metabolism. Cancer Chemother Pharmacol, 56(4), 370-8. https://doi.org/10.1007/s00280-005-1005-4

Deipolyi, A., Karaosmanoğlu, A., Habito, C., Brannan, S., Wicky, S., Hirsch, J., \& Oklu, R. (2012). The role of bilateral inferior petrosal sinus sampling in the diagnostic evaluation of Cushing syndrome. Diagn Interv Radiol, 18, 132-138. https://doi.org/10.4261/1305-3825.DIR.4279-11.0

DeVane, C. L., Donovan, J. L., Liston, H. L., Markowitz, J. S., Cheng, K. T., Risch, S. C., \& Willard, L. (2004). Comparative CYP3A4 inhibitory effects of venlafaxine, fluoxetine, sertraline, and nefazodone in healthy volunteers. J Clin Psychopharmacol, 24(1), 4-10. https://doi.org/10.1097/01.jcp.0000104908.75206.26 
Dickmeis, T. (2009). Glucocorticoids and the circadian clock. $J$ Endocrinol, 200(1), 3-22. https://doi.org/10.1677/JOE-08-0415

Edwards, K. M., \& Mills, P. J. (2008). Effects of estrogen versus estrogen and progesterone on cortisol and interleukin-6. Maturitas, 61(4), 330-3. https://doi.org/10.1016/j.maturitas.2008.09.024

Elamin, M. B., Murad, M. H., Mullan, R., Erickson, D., Harris, K., Nadeem, S., ... Montori, V. M. (2008). Accuracy of Diagnostic Tests for Cushing's Syndrome: A Systematic Review and Metaanalyses. $J$ Clin Endocrinol Metab, 93(5), 1553-1562. https://doi.org/10.1210/jc.2008-0139

Esfahanian, F. \& Kazemi, R. (2010). Overnight dexamethasone suppression test in the diagnosis of Cushing's disease. Acta Med Iran, 48(4), 222-5.

Faggiano, A., Pivonello, R., Melis, D., Filippella, M., Di Somma, C., Petretta, M., Lombardi, G., \& Colao, A. (2003). Nephrolithiasis in Cushing's disease: prevalence, etiopathogenesis, and modification after disease cure. J Clin Endocrinol Metab, 88(5), 2076-80. https://doi.org/10.1210/jc.2002-021494

Faghih, R. T., Savla, K., Dahleh, M. A., \& Brown, E. N. (2011). A feedback control model for cortisol secretion. Conf Proc IEEE Eng Med Biol Soc, 2011, 716-9. https://doi.org/10.1109/IEMBS.2011.6090162

Fahmi, O. A., Maurer, T. S., Kish, M., Cardenas, E., Boldt, S., \& Nettleton, D. (2008). A combined model for predicting CYP3A4 clinical net drug-drug interaction based on CYP3A4 inhibition, inactivation, and induction determined in vitro. Drug Metab Dispos, 36(8), 1698-708. https://doi.org/10.1124/dmd.107.018663

Feelders, R. A., Newell-Price, J., Pivonello, R., Nieman, L. K., Hofland, L., \& Lacroix, A. (2019). Advances in the medical treatment of Cushing's syndrome. Lancet Diabetes Endocrinol, 7(4), 300-312. https://doi.org/10.1016/S2213-8587(18)30155-4

Fegan, P. G., Sanderman, D. D., Krone, N., Bosman, D., Wood, P. J., Stewart, P. M., \& Hanley, N. A. (2007). Cushing's syndrome in women with polycystic ovaries and hyperandrogenism. Nat Clin Pract Endocrinol Metab, 3(11), 778-83. https://doi.org/10.1038/ncpendmet0665

Fernández-Rodríguez, E., Villar-Taibo, R., Pinal-Osorio, I., Cabezas-Agrícola, J. M., Anido-Herranz, U., Prieto, A., Casanueva, F. F., \& Araujo-Vilar, D. (2008). Severe hypertension and hypokalemia as first clinical manifestations in ectopic Cushing's syndrome. Arq Bras Endocrinol Metabol, 52(6), 1066-70.

Findling, J. W., \& Raff, H. (2006). Cushing's syndrome: Important issues in diagnosis and management. J Clin Endocrinol Metab, 91, 3746-53. https://doi.org/10.1210/jc.2006-0997

Findling, J. W., \& Raff, H. (2005). Screening and Diagnosis of Cushing's Syndrome. Endocrinol Metab Clin N Am 34(2), 385-402. https://doi.org/10.1016/j.ecl.2005.02.001

Findling, J. W., Raff, H., \& Aron, D. C. (2004). The Low-Dose Dexamethasone Suppression Test: A Reevaluation in Patients with Cushing's Syndrome. $J$ Clin Endocrinol Metab, 89(3), 1222-6. https://doi.org/10.1210/jc.2003-030207

Ganesh, H. K., George, J., Vimal, M. V., Bandgar, T., Menon, P. S., \& Shah, N. S. (2008). An unusual variant of Cushing syndrome. Endocr Pract, 14(6), 717-20.

Gatta, B., Chabre, O., Cortet, C., Martinie, M., Corcuff, J.B., Roger, P., \& Tabarin, A. (2007). Reevaluation of the combined dexamethasone suppression-corticotropin-releasing hormone test for differentiation of mild Cushing's disease from pseudo-Cushing's Syndrome. J Clin Endocrinol Metab, 92(11), 4290-4293. https://doi.org/10.4158/EP.14.6.717

Giordano, R., Picu, A., Marinazzo, E., D'Angelo, V., Berardelli, R., Karamouzis, I., ... Arvat E. (2011). Metabolic and cardiovascular outcomes in patients with Cushing's syndrome of different aetiologies during active disease and 1 year after remission. Clin Endocrinol (Oxf), 75(3), 354-60. https://doi.org/10.1111/j.1365-2265.2011.04055.x

Gross, B. A., Mindea, S. A., Pick, A. J., Chandler, J. P., \& Batjer, H. H. (2007). Medical management of Cushing disease. Neurosurg Focus, 23 (3), E10. https://doi.org/10.3171/foc.2007.23.3.12

Gutiérrez-Restrepo, J., Latorre-Sierra, G., \& Campuzzano-Maya, G. (2009). Síndrome de Cushing. Medicina \& Laboratorio, 15, (9-10), 411-430.

Hemeryck, A., \& Belpaire, F. M. (2002). Selective serotonin reuptake inhibitors and cytochrome P-450 mediated drug-drug interactions: an update. Curr Drug Metab, 3(1), 13-37. 
https://doi.org/10.2174/1389200023338017

Hinojosa-Amaya, J.M., Cuevas-Ramos, D., \& Fleseriu, M. (2019). Medical Management of Cushing's Syndrome: Current and Emerging Treatments. Drugs, 79(9), 935-956. https://doi.org/10.1007/s40265-019-01128-7.

Hopkins, R. L., \& Leinung, M. C. (2005). Exogenous Cushing's Syndrome and Glucocorticoid Withdrawal. Endocrinol Metab Clin N Am, 34, 371-384. https://doi.org/10.1016/j.ecl.2005.01.013

Ilias, I., Torpy, D. J., Pacak, K., Mullen, N., Wesley, R. A., \& Nieman, L. K. (2005). Cushing's syndrome due to ectopic corticotropin secretion: twenty years' experience at the National Institutes of Health. $J$ Clin Endocrinol Metab, 90(8), 4955-62. https://doi.org/10.1210/jc.2004-2527

Isidori, A. M., Sbardella, E., Zatelli, M. C., Boschetti, M., Vitale, G., Colao, A., Pivonello, R., \& ABC Study Group. (2015). Conventional and nuclear medicine imaging in ectopic Cushing's syndrome: a systematic review. Clin Endocrinol Metab, 100(9), 3231-44. https://doi.org/10.1210/JC.2015-1589

Isidori, A. M., Kaltsas, G. A., Pozza, C., Frajese, V., Newell-Price, J., Reznek, R. H., ... Besser, G. M. (2006). The ectopic adrenocorticotropin syndrome: clinical features, diagnosis, management, and long-term follow-up. $J$ Clin Endocrinol Metab, 91(2), 371-7. https://doi.org/10.1210/jc.2005-1542

Isoherranen, N., Kunze, K. L., Allen, K. E., Nelson, W. L., \& Thummel, K. E. (2004). Role of itraconazole metabolites in CYP3A4 inhibition. Drug Metab Dispos, 32(10), 1121-31. https://doi.org/10.1124/dmd.104.000315

Jones, D. R., Gorski, J. C., Hamman, M. A., Mayhew, B. S., Rider, S., \& Hall, S. D. (1999). Diltiazem inhibition of cytochrome P-450 3A activity is due to metabolite intermediate complex formation. J Pharmacol Exp Ther, 290(3), 1116-25.

Kalman, B. A., \& Grahn, R. E. (2004). Measuring Salivary Cortisol in the Behavioral Neuroscience Laboratory. $J$ Undergrad Neurosci Educ, 2(2), A41-9.

Karmath, B.M. \& Ojo OB. (2008). Cushing's syndrome. Hosp Physician, 44(4), 25-29.

Kita, M., Sakalidou, M., Saratzis, A., Ioannis, S. \& Avramidis, A. (2007). Cushing's syndrome in pregnancy: report of a case and review of the literature. Hormones (Athens), 6(3), 242-6.

Klose, M., Lange, M., Rasmussen, A. K., Skakkebaek, N. E., Hilsted, L., Haug, E., Andersen, M., \& Feldt-Rasmussen, U. (2007). Factors influencing the adrenocorticotropin test: role of contemporary cortisol assays, body composition, and oral contraceptive agents. J Clin Endocrinol Metab, 92(4), 1326-1333. https://doi.org/10.1210/jc.2006-1791

Lacroix, A. (2009). ACTH independent macronodular adrenal hyperplasia. Best Pract Res Clin Endocrinol Metab, 23, 245-59. https://doi.org/10.1016/j.beem.2008.10.011

Lahera-Vargas, M., \& da Costa, C. V. (2009). Prevalencia, etiología y cuadro clínico del síndrome de Cushing. Endocrinol Nutr, 56, 32-9. https://doi.org/10.1016/S1575-0922(09)70191-3

Lavalle-González, F. J., Villareal-Pérez, J. Z., González-González, G., Montes-Villarreal, J., Mancillas-Adame, L., Támez-Pérez, H. E., ... Valencia-García, J. E. (2011). Validación de la medición de cortisol en saliva de una población de adultos jóvenes. Rev Endocrinol Nutr, 19(4), 146-148.

Lee, J., Kyoung, M., Ko, S., Koh, J., Kim, B., Kim, S., ... Yoo, S. (2017). Clinical Guidelines for the Management of Adrenal Incidentaloma. Endocrinol Metab (Seoul), 32(2), 200-218. https://doi.org/10.3803/EnM.2017.32.2.200

Lila, A., Sarathi, V., Jagtap, V.S., Bandgar, T., Menon, P., \& Shah, N. (2011). Cushing's syndrome: Stepwise approach to diagnosis. Indian $J$ Endocrinol Metab, 15(Supp14), S317-S321. https://doi.org/10.4103/2230-8210.86974

Lindsay, J. R., \& Nieman, L. K. (2005). The hypothalamic pituitary-adrenal axis in pregnancy: Challenges in disease detection and treatment. Endocr Rev, 26(6), 775-799. https://doi.org/10.1210/er.2004-0025

Lindsay, J. R., Jonklaas, J., Oldfield, E. H., \& Nieman, L. K. (2005). Cushing's syndrome during pregnancy: personal experience and review of the literature. $J$ Clin Endocrinol Metab, 90, 3077-3083. https://doi.org/10.1210/jc.2004-2361

Louiset, E., Contesse, V., Groussin, L., Cartier, D., Duparc, C., Perraudin, V., Bertherat, J., \& Lefebvre, H. (2008). Expression of vasopressin receptors in ACTH-independent macronodular bilateral adrenal hyperplasia causing Cushing's syndrome: molecular, immunohistochemical and pharmacological correlates. $J$ Endocrinol, 
196(1), 1-9. https://doi.org/10.1677/JOE-07-0413

Luo, G., Cunningham, M., Kim, S., Burn, T., Lin, J., Sinz, M., ... Gan, L. S. (2002). CYP3A4 induction by drugs: correlation between a pregnane $\mathrm{X}$ receptor reporter gene assay and CYP3A4 expression in human hepatocytes. Drug Metab Dispos, 30(7), 795-804. https://doi.org/10.1124/dmd.30.7.795

Ma, R. C., Chan, W. B., So, W. Y., Tong, P. C., Chan, J. C., \& Chow, C. C. (2005). Carbamazepine and false positive dexamethasone suppression tests for Cushing's syndrome. BMJ, 330(7486), 299-300. https://doi.org/10.1136/bmj.330.7486.299

Makras, P., Toloumis, G., Papadogias, D., Kaltsas, G. A., \& Besser, M. (2006). The diagnosis and differential diagnosis of endogenous Cushing's syndrome. Hormones (Athens), 5(4), 231-50.

Mancini, T., Porcelli, T., \& Giustina, A. (2010). Treatment of Cushing disease: overview and recent findings. Ther Clin Risk Manag, 6, 505-16. https://doi.org/10.2147/TCRM.S12952

Maronpot, R. R., Yoshizawa, K., Nyska, A., Harada, T., Flake, G., Mueller, G., ... Ward, J. M. (2010). Hepatic $\begin{array}{llll}\text { enzyme induction: } \quad \text { histopathology. Toxicol } & \text { Pathol, }\end{array}$ https://doi.org/10.1177/0192623310373778

Master-Hunter, T., \& Heiman, D. L. (2006). Amenorrhea: Evaluation and Treatment. Am Fam Physician, 73(8), $1374-1382$.

Meikle, A. W., Findling, J., Kushnir, M. M., Rockwood, A. L., Nelson, G. J., \& Terry, A. H. (2003). Pseudo-Cushing syndrome caused by fenofibrate interference with urinary cortisol assayed by high-performance liquid chromatography. $J$ Clin Endocrinol Metab, 88(8), 3521-4. https://doi.org/10.1210/jc.2003-030234

Ministerio del Poder Popular para la Salud de la República Bolivariana de Venezuela. (2009). Anuario de Mortalidad 2009. Retrieved from http://www.bvs.org.ve/anuario/Anuario2009.pdf

Murakami, H., Nigawara, T., Sakihara, S., Kageyama, K., Yamashita, M., Matsuki, K., ... Suda, T. (2010). The frequency of type 2 diabetic patients who meet the endocrinological screening criteria of subclinical Cushing's disease. Endocr J, 57(3), 267-72. https://doi.org/https://doi.org/10.1507/endocrj.K09E-352

Nader, N., Raverot, G., Emptoz-Bonneton, A., Déchaud, H., Bonnay, M., Baudin, E., \& Pugeat, M. (2006). Mitotane has an estrogenic effect on sex hormone-binding globulin and corticosteroid-binding globulin in humans. J Clin Endocrinol Metab, 91(6), 2165-70. https://doi.org/10.1210/jc.2005-2157

Newell-Price, J. (2009). Diagnosis/differential diagnosis of Cushing's syndrome: a review of best practice. Best Pract Res Clin Endocrinol Metab, 23(Suppl 1), S5-14. https://doi.org/10.1016/S1521-690X(09)70003-X

Newell-Price, J., Bertagna, X., Grossman, A. B., \& Nieman, L. K. (2006). Cushing's syndrome. Lancet, 367, 1605-17. https://doi.org/10.1016/S0140-6736(06)68699-6

Nieman, L. (2018). Diagnosis of Cushing's Syndrome in the Modern Era. Endocrinol Metab Clin North Am ,47(2), 259-273. https://doi.org/10.1016/j.ecl.2018.02.001

Nieman, L. K., Biller, B. M., Findling, J. W., Newell-Price, J., Savage, M. O., Stewart, P. M., \& Montori, V. M. (2008). The diagnosis of Cushing's syndrome: an Endocrine Society Clinical Practice Guideline. J Clin Endocrinol Metab, 93(5), 1526-40. https://doi.org/10.1210/jc.2008-0125

Nishimoto, K., Nakagawa, K., Li, D., Kosaka, T., Oya, M., Mikami, S., ... Mukai, K. (2010). Adrenocortical Zonation in Humans under Normal and Pathological Conditions. J Clin Endocrinol Metab, 95(5), 2296-305. https://doi.org/10.1210/jc.2009-2010

Nock, B., Wich, M., \& Cicero, T. J. (1997). Chronic exposure to morphine increases corticosteroid-binding globulin. J Pharmacol Exp Ther, 282(3), 1262-8.

Oliver, R.L., Davis, J.R. \& White, A. (2003). Characterisation of ACTH Related Peptides in Ectopic Cushing's Syndrome. Pituitary, 6(3), 119-26.

Pacak, K., Ilias, I., Chen, C. C., Carrasquillo, J. A., Whatley, M., \& Nieman, L. K. (2004). The role of [(18)F] fluorodeoxyglucose positron tomography and [(111)In]-diethylenetriaminepentaacetate-D-Phe-pentetreotide scintigraphy in the localization of ectopic adrenocorticotropin-secreting tumors causing Cushing's syndrome. J Clin Endocrinol Metab, 89(5), 2214-21. https://doi.org/10.1210/jc.2003-031812

Paus, R. (2011). A neuroendocrinological perspective on human hair follicle pigmentation. Pigment Cell 
Melanoma Res, 24(1), 89-106. https://doi.org/10.1111/j.1755-148X.2010.00808.x

Perucca, E. (2006). Clinically relevant drug interactions with antiepileptic drugs. Br J Clin Pharmacol, 61(3), 246255. https://doi.org/10.1111/j.1365-2125.2005.02529.x

Pivonello, R., De Matino, M. C., De Leo, M., Lombardi, G., \& Colao, A. (2008). Cushing's Syndrome. Endocrinol Metab Clin North Am, 37(1), 135-49. https://doi.org/10.1016/j.ecl.2007.10.010

Rae, J. M., Johnson, M. D., Lippman, M. E., \& Flockhart, D. A. (2001). Rifampin is a selective, pleiotropic inducer of drug metabolism genes in human hepatocytes: studies with cDNA and oligonucleotide expression arrays. J Pharmacol Exp Ther, 299(3), 849-57.

Raff, H., \& Findling, J. W. (2003). A physiologic approach to diagnosis of the Cushing syndrome. Ann Intern Med, 138, 980-9. https://doi.org/10.7326/0003-4819-138-12-200306170-00010

Ripp, S. L., Mills, J. B., Fahmi, O. A., Trevena, K. A., Liras, J. L., Maurer, T. S., \& de Morais, S. M. (2006). Use of immortalized human hepatocytes to predict the magnitude of clinical drug-drug interactions caused by CYP3A4 induction. Drug Metab Dispos, 34(10), 1742-8. https://doi.org/10.1124/dmd.106.010132

Rizk, A., Honegger, J., Milian, M., \& Psaras, T. (2012). Treatment Options in Cushing's Disease. Clin Med Insights Oncol, 6, 75-84. https://doi.org/10.4137/CMO.S6198

Rüegg, S. (2002). Dexamethasone/phenytoin interactions: neurooncological concerns. Swiss Med Wkly, 132(29-30), 425-6.

Sakihara, S., Kageyama, K., Oki, Y., Doi, M., Iwasaki, Y., ... Suda T. (2010). Evaluation of Plasma, Salivary, and Urinary Cortisol Levels for Diagnosis of Cushing's Syndrome. Endocr J, 57 (4), 331-7. https://doi.org/https://doi.org/10.1507/endocrj.K09E-340

Sarver, J. G., Bachmann, K. A., Zhu, D., \& Klis, W. A. (1998). Ethosuximide is primarily metabolized by CYP3A when incubated with isolated rat liver microsomes. Drug Metab Dispos, 26(1), 78-82.

Savage, M. O., Chan, L. F., Grossman, A. B., \& Storr, H. L. (2008). Work-up and management of Cushing's syndrome. Curr Opin Endocrinol Diabetes Obes, 15(4), 346-51. https://doi.org/10.1097/MED.0b013e328305082f

Scheinfeld, N. (2003). Cimetidine: a review of the recent developments and reports in cutaneous medicine. Dermatol Online J, 9(2), 4.

Shahani, S., Nudelman, R. J., Nalini, R., Kim, H. S. \& Samson, S. L. (2010). Ectopic corticotropin-releasing hormone (CRH) syndrome from metastatic small cell carcinoma: a case report and review of the literature. Diagn Pathol, 5, 56. https://doi.org/10.1186/1746-1596-5-56

Slominski, A., Wortsman, J., Luger, T., Paus, R., \& Solomon, S. (2000). Corticotropin Releasing Hormone and Proopiomelanocortin Involvement in the Cutaneous Response to Stress. Physiol Rev, 80(3), 979-1020. https://doi.org/10.1152/physrev.2000.80.3.979

Terzolo, M., Pia, A., \& Reimondo, G. (2012). Subclinical Cushing's syndrome: definition and management. Clin Endocrinol (Oxf), 76(1), 12-8. https://doi.org/10.1111/j.1365-2265.2011.04253.x

Tiong, K., \& Falhammar, H. (2009). Carbamazepine and falsely positive screening tests for Cushing's syndrome. $N$ $Z$ Med J, 122(1288), 100-2.

Tsagarakis, S., Vassiliadi, D., \& Thalassinos, N. (2006). Endogenous subclinical hypercortisolism: Diagnostic uncertainties and clinical implications. $J$ Endocrinol Invest., 29(5), 471-82. https://doi.org/10.1007/BF03344133

Utz, A., \& Biller, B. M. (2007). The role of bilateral inferior petrosal sinus sampling in the diagnosis of Cushing's syndrome. Arq Bras Endocrinol Metabol, 51(8), 1329-38.

Vartiainen, E. (2008). Controlling the cardiovascular disease epidemic. J Intern Med, 263(6), 623-5. https://doi.org/10.1161/CIRCULATIONAHA.115.008728

Vásquez, H.A., Plua, W., González, L., Alcivar, J., Barboza, H., Bermúdez-Pírela, V., \& Peña-LE, M. (2018). Indicadores utilizados en la práctica clínica para el diagnóstico de obesidad. Barranquilla, Colombia. Ediciones Universidad Simón Bolívar.

Velez, D. A., Mayberg, M. R., \& Ludlam, W. H. (2007). Cyclic Cushing syndrome: definitions and treatment implications. Neurosurg Focus, 23(3), E4. https://doi.org/10.3171/foc.2007.23.3.5 
Vilar, L., Freitas, Mda. C., Faria, M., Montenegro, R., Casulari, L. A., Naves, L., \& Bruno, O. D. (2007). Pitfalls in the Diagnosis of Cushing's Syndrome. Arq Bras Endocrinol Metabol, 51(8), 1207-16.

Vilar, L., Naves, L. A., Freitas, M. C., Moura, E., Canadas, V., Leal, E., \& Casulari, L. A. (2007). Endogenous Cushing's syndrome: Clinical and laboratorial features in 73 cases. Arq Bras Endocrinol Metab, 51(4), $566-74$.

Wagner-Bartak, N., Baiomy, A., Habra, M. A., Mukhi, S. V., Morani, A. C., Korivi, B. R., Waguespack, S. G., \& Elsayes, K. M.. (2017). Cushing Syndrome: Diagnostic Workup and Imaging Features, With Clinical and Pathologic Correlation. AJR Am J Roentgenol, 209 (1), 19-32. https://doi.org/10.2214/AJR.16.17290

World Health Organization. (2010). Global status report on non-communicable diseases. Retrieved from: http://www.who.int/nmh/publications/ncd_report_full_en.pdf

Zeiger, M. A., Thompson, G. B., Duh, Q. Y., Hamrahian, A. H., Angelos, P., Elaraj, D., Fishman, E., \& Kharlip, J. (2009). Medical Guidelines for the Management of Adrenal Incidentalomas: executive summary of recommendations. Endocr Pract, 15(5), 450-3. https://doi.org/10.4158/EP.15.5.450

Zeldin, R. K., \& Petruschke, R. A. (2004). Pharmacological and therapeutic properties of ritonavir-boosted protease inhibitor therapy in HIV-infected patients. $J$ Antimicrob Chemother, 53(1), 4-9. https://doi.org/10.1093/jac/dkh029

\section{Copyrights}

Copyright for this article is retained by the author(s), with first publication rights granted to the journal.

This is an open-access article distributed under the terms and conditions of the Creative Commons Attribution license (http://creativecommons.org/licenses/by/4.0/). 